\title{
PERFORMANCE AND DIGESTIVE TRACT DEVELOPMENT OF YOUNG BROILER CHICKENS FED MASH BASAL DIET SUPPLEMENTED WITH RICE HULLS OR WHEAT POLLARD AT DIFFERENT LEVELS
}

\author{
S. Hartini, M. Kayadoe and D.D. Rahardjo \\ Faculty of Animal Husbandry, Fishery and Marine Science, Papua State University, \\ Jl. Gunung Salju Amban, Manokwari 98314, Papua Barat-Indonesia \\ Corresponding E-mail: shartini2003@yahoo.com
}

Received September 08, 2013; Accepted November 16, 2013

\begin{abstract}
ABSTRAK
Sebuah penelitian dilakukan untuk mengetahui pengaruh suplementasi sumber polisakarida nonpati (NSP) tidak-larut yang berbeda pada level $0,20,40,60 \mathrm{~g} / \mathrm{kg}$ terhadap performan dan perkembangan saluran pencernaan ayam broiler muda (doc-21 d). Hasil penelitian menunjukkan bahwa tidak ada interaksi antara sumber dan level NSP tidak-larut pada setiap variabel yang diukur. Efek signifikan hanya didapatkan pada level NSP tidak-larut. Ayam broiler muda yang diberi ransum bentuk mash yang disuplementasi dengan 6\% NSP tidak-larut menurunkan pertambahan berat badan $(\mathrm{P}<0,05)$ dan memberikan rasio pertambahan berat badan:konsumsi yang jelek $(\mathrm{P}<0,01)$. Ransum tidak berpengaruh signifikan pada konsumsi ransum (KR), berat relatif dari gizzard, jejunum-ileum, usus buntu, dan berat relatif pankreas. Level NSP tidak-larut mempengaruhi berat digesta saluran pencernaan dengan berat digesta jejunum-ileum $(\mathrm{P}<0,01)$ didapatkan tertinggi pada suplementasi 6\% NSP tidak-larut. Berat kering digesta jejunum-ileum dan kadar air feses juga tidak dipengaruhi oleh ransum $(\mathrm{P} \geq 0,05)$. Hasil penelitian menunjukkan bahwa NSP tidak-larut dapat disuplementasikan pada ransum ayam broiler muda sampai dengan level 4\%. Ada kemungkinan bahwa peningkatan performan ayam broiler muda yang disuplementasi NSP tidak-larut sampai level 4\% adalah karena meningkatnya KR dan kondisi usus yang lebih baik. Suplementasi NSP tidak-larut tidak menghasilkan dampak yang kuat karena ransum diberikan dalam bentuk mash.
\end{abstract}

Kata kunci : NSP tidak-larut, performan broiler, konsumsi ransum, berat gizzard relatif

\begin{abstract}
An experiment was conducted to determine the effect of different insoluble non-starch polysaccharides (NSP) sources supplementation at levels $0,20,40,60 \mathrm{~g} / \mathrm{kg}$ on performance and digestive tract development of young broilers (doc-21 d). Results showed that there were no interactions between insoluble NSP sources and levels at any variable measured. Only levels of insoluble NSP had significant effect. Young broilers fed mash basal diet supplemented with 6\% insoluble NSP decreased body weight gain $(\mathrm{P}<0.05)$ and impaired gain-to-feed ratio $(\mathrm{P}<0.01)$. Diets did not have a significant effect on feed intake (FI), in addition to the relative weight of gizzard, jejunum-ileum, caeca, and pancreas. Levels of NSP affected the weight of gastrointestinal digesta with jejunal-ileal digesta was found to be the highest $(\mathrm{P}<0.01)$ in 6\% insoluble NSP supplementation. Dry matter of jejunal-ileal digesta and excreta moisture also did not significantly affected by diets $(\mathrm{P} \geq 0.05)$. The present study demonstrated that the insoluble NSP can be supplemented to young broilers diet up to $4 \%$. It is likely that increased performance of young broilers supplemented with insoluble NSP up to $4 \%$ was due to increase FI and a better gut environment. The supplementation of insoluble NSP did not produce strong impact considering that the diets were given in mash form.

Keywords: insoluble NSP, broiler performance, feed intake, relative gizzard weight
\end{abstract}

\section{INTRODUCTION}

Broilers chickens have been known as having rapid growth rate particularly during the early period of growth. With increasing demand for broiler chickens production, while feed 
production remains static, the inclusion of a greater range of non-starch polysaccharides (NSP) in broiler chickens diet is unavoidable. This is due to the vast majority of NSP found in cereal grains which occupy about $70 \%$ of the broiler chickens diets. In recent years, many studies have reported the positive effect of insoluble NSP in poultry diets. Starch digestibility was higher when a moderate level of insoluble fiber was present in the diet (Hetland et al., 2004). Bao and Choct (2010) reported that insoluble NSP was able to increase population of non pathogen microorganism to stimulate immune system. Study by Gonzalez-Alverado et al. (2007) also indicated that a minimum level of insoluble NSP was needed to improve the intestinal health of broiler chickens. They found that the inclusion of hulls reduced gizzard $\mathrm{pH}$. It is believed that the lowered gizzard $\mathrm{pH}$ can prevent pathogen microorganisms to colonize the intestinal tract (Engberg et al., 2004). Increased gizzard weight and lowered gizzard $\mathrm{pH}$ was also found on broiler chickens fed a basal diet added with hulls (Sacranie et al., 2012).

Rice hulls and wheat pollard are by-products of cereal grains which can be easily found in many places in Indonesia. Rice hulls and wheat pollard contain high insoluble NSPs. Rice hull was reported to contain $11.5 \% \mathrm{DM}$ of insoluble NSP and $0.21 \%$ soluble NSP (Hartini and Choct, 2010), whereas wheat pollard contains 33.6\% DM of insoluble NSP and $1.7 \%$ soluble NSP (Choct, 1997). Although insoluble NSP have been reported as having a beneficial effect in poultry production, the extent to which they can be added to young broiler diets without compromising broiler performances still need to be clarified. In addition, poultry are known to digest little or no fiber. The objectives of the current study therefore, were to observe the effect of rice hulls or wheat pollard supplementation on mash basal diets on performance and digestive characteristics of young broiler chickens.

\section{MATERIALS AND METHODS}

\section{Experimental Diets and Birds' Management}

Seven dietary treatments were used in this experiment. A commercial mash starter diet (HG 11 Bravo produced by Charoen Pokphan) was supplemented with two insoluble NSP sources. Insoluble NSP sources were supplied from rice hulls and wheat pollard at 2, 4, and 6 percent of the diets. Rice hulls were finely grounded before added to the diet. Wheat pollard was provided by PT. Eastern Flour Mills, Makassar, SouthSulawesi.

Ninety-six male broiler chicks obtained from a commercial hatchery at one day of age were used in the experiment. Four birds were randomly allocated to each of 24 cages with three cages per treatment. Chicks were given free access to both water and feed (mash form) until 21 days of age. Pens were illuminated $24 \mathrm{~h}$ per day.

\section{Performance Measurement}

Body weight and feed intake (g/bird/day) were determined at the beginning and termination of the experiment ( $21 \mathrm{~d}$ ). Gain-to-feed ratio (FCE) was calculated on a bird/d basis.

\section{Sample collection and analyses}

At the end of the experiment (21d), two birds from each of three replicates per treatment were selected based on proximity to average bird weight per cage, killed by dissecting at jugular's vein and used to measure the variable below.

\section{Gastrointestinal Weight and Gastrointestinal Digesta}

After the birds were killed, the body cavity was immediately opened, and gastrointestinal tract (GIT) including gizzard was removed and cut into segments, viz gizzard, jejunum-ileum (measured from the end of duodenal loop to ileocecocolic junction) and caeca. The GIT was weighed prior to and after removal of digesta. The empty section weights were expressed as a percentage of body weight $(\% \mathrm{BW})$. The pancreas was also removed and weighed. The jejunal- ileal digesta collected was analysed for dry matter (DM) content.

\section{Dry Matter}

Dry matter of the jejunal-ileal digesta was determined using a drying oven at $105^{\circ} \mathrm{C}$ for $24 \mathrm{~h}$. Dry matter feses was determined using a drying oven at $80^{\circ} \mathrm{C}$ for 3 days.

\section{Statistical Analysis}

The data obtained were analyzed statistically using GLM procedure appropriate for factorial design 2x4 (SPSS 16, 2007). After a significant $F$ test $(\mathrm{P}<0.05)$, Duncan's multiple range test was used to inspect differences among group means. 


\section{RESULTS}

\section{Birds Performance}

There were no significant interactions between insoluble NSP sources and level for body weight gain (BWG), feed intake (FI), and gain-tofeed ratio (FCE) measured (Table 1). Levels of insoluble NSP in the diet significantly affected BWG $(\mathrm{P}<0.05)$ and FCE $(\mathrm{P}<0.01)$, whereas the effect of insoluble NSP sources on performance were not significantly different $(\mathrm{P} \geq 0.05)$. BWG and FCE of birds fed mash basal diet supplemented with $6 \%$ insoluble NSP had significantly poorer $\mathrm{BWG}$ and $\mathrm{FCE} \quad(\mathrm{P}<0.01)$ compared to others which were not significantly different (Table 1). There was no significant effect of diets on FI $(\mathrm{P} \geq 0.05)$, but numerically birds supplemented with $6 \%$ insoluble NSP had the lowest FI.

\section{Gastrointestinal Measurements, Dry Matter Digesta and Excreta Moisture}

The effect of dietary treatments on the weight of digestive organs (gizzard, jejunumileum, pancreas, and caeca), gastrointestinal (GIT) digesta (gizzard, jejunum-ileum, and caeca), DM jejunal-ileal digesta, and excreta moisture are presented on Table 2. The weight of digestive organs and GIT digesta is expressed per $100 \mathrm{~g}$ body weight. Dietary treatments had no effect on gizzard, jejunal-ileal, pancreas, and caecal weight $(P \geq 0.05)$. Only level of insoluble NSP affected the weight of GIT digesta $(\mathrm{P}<0.01)$, whereas the effect of insoluble NSP sources was not significantly different $\quad(\mathrm{P} \geq 0.05)$. The supplementation of insoluble NSP at $6 \%$ increased jejunal-ileal digesta. The ranking of insoluble NSP level according to total jejunal-ileal digesta, highest to lowest is $6 \%, 0 \%, 4 \%$, and $2 \%$ (Table 2). Although not statistically different, the relative weight of gizzard digesta tended to be highest in birds fed mash basal diet supplemented with $6 \%$ insoluble NSP, followed by $2 \%, 4 \%$ and $0 \%$ as the lowest. Diets had no significant effect on dry matter (DM) jejunal-ileal digesta, as well as excreta moisture measured $(\mathrm{P} \geq 0.05)$. However, numerically, supplementation of insoluble NSP decreased excreta moisture and increased DM jejunal-ileal digesta.

Table 1. Body Weight Gain (BWG), Feed Intake (FI), and Gain-to-Feed Ratio (FCE) of Young Broiler Chickens (21 d) Fed Mash Basal Diet Supplemented with Rice Hulls or Wheat pollard at Different Level

\begin{tabular}{lccc}
\hline & BWG $(\mathrm{g} / \mathrm{b} / \mathrm{d})$ & FI $(\mathrm{g} / \mathrm{b} / \mathrm{d})$ & FCE \\
\hline NSP sources: & & & \\
Rice Hulls & 39.11 & 58.81 & 0.67 \\
Wheat Pollard & 38.20 & 57.00 & 0.67 \\
Pooled SEM & 0.696 & 0.984 & 0.004 \\
NSP level (\%): & & & \\
$\quad 0$ & $38.44^{\mathrm{a}}$ & 56.99 & $0.677^{\mathrm{a}}$ \\
$\quad 39.55^{\mathrm{a}}$ & 58.25 & $0.680^{\mathrm{a}}$ \\
$\quad 4$ & $40.62^{\mathrm{a}}$ & 60.36 & $0.675^{\mathrm{a}}$ \\
$\quad 6$ & $36.01^{\mathrm{b}}$ & 56.04 & $0.642^{\mathrm{b}}$ \\
Pooled SEM & 0.868 & 1.392 & 0.006 \\
Variable: & & P-Value & \\
NSP sources & 0.367 & 0.213 & 0.607 \\
NSP level & 0.026 & 0.188 & 0.002 \\
NSP sources x level & 0.430 & 0.688 & 0.272 \\
\hline
\end{tabular}

$\overline{\mathrm{a}, \mathrm{b}, \mathrm{c}}$ Mean values within a column bearing different superscript differ significantly $(\mathrm{P}<0.05)$ 
Table 2. Gastrointestinal (GIT) Weight and Digesta, DM of Jejunal-ileal Digesta and Excreta Moisture of Young Broiler Chickens (21 d) Fed Mash Basal Diet Supplemented with Rice Hulls or Wheat Pollard at Different Level

\begin{tabular}{|c|c|c|c|c|c|c|c|c|c|}
\hline & \multicolumn{7}{|c|}{ Weight (g/100g body weight) } & \multirow[b]{2}{*}{$\begin{array}{c}\text { Excreta } \\
\text { Moisture } \\
(\%)\end{array}$} & \multirow{2}{*}{$\begin{array}{c}\text { DM } \\
\text { Jejunal } \\
\text { Ileal } \\
\text { digesta } \\
(\%)\end{array}$} \\
\hline & $\begin{array}{l}\text { Empty } \\
\text { Gizzard }\end{array}$ & $\begin{array}{c}\text { Empty } \\
\text { Jejunum } \\
\text {-Ileum }\end{array}$ & $\begin{array}{l}\text { Empty } \\
\text { Caeca }\end{array}$ & Pancreas & $\begin{array}{c}\text { Gizzard } \\
\text { digesta }\end{array}$ & $\begin{array}{l}\text { Jejunal- } \\
\text { Ileal } \\
\text { digesta }\end{array}$ & $\begin{array}{l}\text { Caecal } \\
\text { digesta }\end{array}$ & & \\
\hline \multicolumn{10}{|l|}{ NSP sources: } \\
\hline Rice hulls & 1.69 & 2.31 & 0.28 & 0.27 & 0.76 & 0.25 & 0.17 & 83.2 & 22.12 \\
\hline Wheat Pollard & 1.59 & 2.40 & 0.28 & 0.26 & 1.07 & 0.25 & 0.25 & 83.9 & 23.129 \\
\hline Pooled SEM & 0.065 & 0.100 & 0.024 & 0.025 & 0.199 & 0.021 & 0.05 & 0.539 & 2.663 \\
\hline \multicolumn{10}{|l|}{ NSP level (\%): } \\
\hline 0 & 1.61 & 2.54 & 0.33 & 0.22 & 0.67 & $0.26^{\mathrm{a}}$ & 0.24 & 85.1 & 16.64 \\
\hline 2 & 1.65 & 2.32 & 0.29 & 0.27 & 0.92 & $0.16^{\mathrm{c}}$ & 0.16 & 83.3 & 26.00 \\
\hline 4 & 1.71 & 2.13 & 0.22 & 0.33 & 0.84 & $0.24^{\mathrm{b}}$ & 0.16 & 83.2 & 20.76 \\
\hline 6 & 1.60 & 2.42 & 0.28 & 0.26 & 1.24 & $0.34^{\mathrm{a}}$ & 0.29 & 82.6 & 27.08 \\
\hline Pooled SEM & 0.092 & 0.142 & 0.034 & 0.039 & 0.281 & 0.029 & 0.071 & 0.762 & 3.767 \\
\hline \multicolumn{10}{|l|}{ Variable: } \\
\hline NSP sources & 0.267 & 0.519 & 0.922 & 0.799 & 0.283 & 0.889 & 0.300 & 0.372 & 0.794 \\
\hline NSP level & 0.799 & 0.262 & 0.207 & 0.231 & 0.557 & 0.005 & 0.499 & 0.149 & 0.216 \\
\hline NSP sources x level & 0.612 & 0.966 & 0.886 & 0.491 & 0.344 & 0.406 & 0.595 & 0.403 & 0.560 \\
\hline
\end{tabular}

$\overline{\mathrm{a}, \mathrm{b}, \mathrm{c}}$ mean values within a column bearing different superscript differ significantly $(\mathrm{P}<0.05)$

\section{DISCUSSION}

The result showed that there were no interactions between insoluble NSP sources and levels at any variable measured. The effect of insoluble NSP sources was also not significantly different. Rice hulls was reported to contain 11.5 $\%$ DM of insoluble NSP and $0.21 \%$ soluble NSP (Hartini and Choct, 2010), whereas wheat pollard contains $33.6 \%$ DM of insoluble NSP and 1.7\% soluble NSP (Choct, 1997). The lack of profound effect between rice hulls and wheat pollard was suggested probably due to two reasons. First, both of the feedstuffs contain the high insoluble NSP, eventually they exerted similar responses. Second, the soluble NSP contain in the wheat pollard may of low viscosity. Soluble NSP of low viscosity (below $10 \mathrm{~m} \mathrm{Pa.s}$ ) possessed no negative effect on intestinal starch digestibility, FI, egg production and BWG (Hartini and Choct, 2010).
Inclusion of high fiber feedstuffs will reduce nutrient concentration and birds will try to compensate for reduction in nutrient concentration by increasing FI (Hetland et al., 2003). The results showed only a slight numerical increase on birds fed mash basal diet supplemented with $2 \%$ and $4 \%$ insoluble NSP compared to control diet, but a numerical decrease on FI at $6 \%$ insoluble addition. The marginal response on FI was suggested due to the concentration of insoluble NSP on the diets had little impact on dietary energy availability. However, based on the previous suggestion, it could have been expected that addition of $6 \%$ insoluble NSP in the diet would have the highest FI. The fact that FI significantly decreased with supplementation of $6 \%$ insoluble NSP indicated that $6 \%$ addition of insoluble NSP to young broiler diets is too high. The result was in agreement with the finding by Basak et al. (2002) 
and Olugbemi et al. (2010) who found that high fiber feedstuff can be incorporated safely to broiler diets up to $5 \%$. In contrast, Hetland and Svihus (2001) and Hetland et al. (2003) found that inclusion of insoluble NSP in the broilers diets can be up to $10 \%$. This indicated that the effect of insoluble NSP is dependent on physical and chemical nature of fiber. However, the fact that birds received $6 \%$ insoluble NSP supplementation had the highest jejunal-ileal digesta indicated that there was another factor involved in reducing FI.

Birds have no or limited amount of cellulase, the enzyme to digest cellulose or insoluble fiber. The lack digestion of insoluble fiber was reported to increase bulk of digesta in the intestinal tract (Hetland et al., 2004). Savory (1985) found that insoluble NSP remained longer in the gizzard, but once it is emptied from the gizzard, it passes through the gut quickly. However, Hetland et al. (2004) found that the ability of insoluble fiber to exert this effect diminished when insoluble fiber was given in a mash form. The results on the present study were partly in agreement with the finding by Hetland et al. (2004). For birds received $6 \%$ insoluble NSP addition, their gizzard which is the pacemaker for the entire tract failed to drive force the peristaltic movement of the birds' gastrointestinal tract, causing the accumulation of intestinal digesta, consequently delayed gizzard emptying. Delay gizzard emptying was suggested to induce the feeling of satiety of birds which eventually can reduce FI (Savory, 1999).

Choct et al. (1992) found that increased the present of undigested materials in the gut led to increase in microbial numbers, as well as microbial activity (Choct et al., 1999). This microbial increase can impact on animal wellbeing directly or indirectly by interfering with nutrient digestibilities, thereby reducing performance. This was confirmed by the lowest BWG and poorest FCE on birds receiving 6\% insoluble NSP from the present study. So based on this explanation, it was likely that the slight increase on BWG in birds supplemented with insoluble NSP up to $4 \%$ not only due to increase FI per se but also probably due to a better gut environment.

The proposed mechanism that the increased performance of birds fed diets with hulls was due to stimulation of gizzard function (Hetland et al., 2004) was not supported by the results in the present study. There was no effect of insoluble
NSP levels on relative weight (RW) of gizzard. The RW of digestive organs (jejunum-ileum, gizzard, and pancreas) did not increase despite increased jejunal-ileal and gizzard digesta. This was in contrast with the previous finding that birds will enlarge digestive organs and pancreas in response to the increase in intestinal digesta (Hetland and Svihus, 2001, Hartini and Choct, 2010). The lack of strong impact of insoluble NSP on gizzard weight in the present study might be due to diets was given in mash form. Hetland and Svihus (2001) found similar results on gizzard weight through supplementation of finely-ground oat hulls. Less profound effect was also found on gizzard weight of birds fed fine hull than coarse hull (Sacranie et al., 2012). Hartini and Choct (2010), study in laying hens, also failed to get strong difference results on cannibalism mortality between high soluble NSP and high insoluble NSP diets considering the diets were given in mash form. It is likely that the chemical and physical nature of insoluble NSP in mash form did not produce strong effect on gizzard stimulation.

The present study also showed that diets did not have a significant effect on DM jejunal-ileal digesta and excreta moisture. However, numerically there was a decreased in excreta moisture and an increased in jejunal-ileal digesta DM of birds fed basal diet supplemented with insoluble NSP. The result was in accordance with the previous finding by Hartini and Choct (2010), who found an increase in digesta DM of the jejunum and ileum on laying hens fed diets containing high insoluble NSP.

\section{CONCLUSIONS}

The present study demonstrated that insoluble NSP can be supplemented to young broilers diet up to $4 \%$. The increased performance of young broilers supplemented with insoluble NSP up to $4 \%$ was probably due to increase FI and a better gut environment. The supplementation of insoluble NSP did not produce strong impact considering that the diets were given in mash form. The degree of response of insoluble NSP is dependent on the chemical and physical nature of fiber.

\section{ACKNOWLEDGMENTS}

The experimental work presented was made possible through the financial assistance provided 
by State University of Papua through the DIPA, contract no. 288.D/UN42/KU/2013, May 16, 2013, under the BOPTN Research Funding, Fundamental research.

\section{REFERENCES}

Bao, Y.M. and M. Choct. 2010. Dietary NSP nutrition and intestial immune system for broiler chickens. World's Poult. Sci. J. 66: 511-517

Basak, B.M.D., A.H. Pramanik and M.S. Rahman. 2002. Azolla (Azolla pinnata) as a feed ingredient in broiler ration. Int. J. Poult. Sci. 1(1):29-34

Choct M., R. J. Hughes, J. Wang and M.R. Bedford. 1999. Effects of a xylanase on individual bird variation, starch digestion throughout the intestine, and ileal and caecal volatile fatty acid production in chickens fed wheat. Br. Poult. Sci. 40 (3):419-422

Choct, M. 1997. Feed non-starch polysaccharides: Chemical structures and nutritional significance. Feed Milling Int. (June): 13-26.

Choct, M., G. Annison and R.P. Trimble. 1992. Soluble wheat pentosans exhibit different anti-nutritive activities in intact and cecectomized broiler chickens. J. Nutr. 122: 2457-2465.

Engberg, R.M., M.S. Hedemann, S. Steenfeldt and B.B. Jensen. 2004. Influence of whole wheat and xylanase on broiler performance and microbial composition and activity in the digestive tract. Poult. Sci. 83:925-938.

Gonzaleź-Alverado, J.M., E. Jimenez-Moreno and G.G. Mateos. 2007. Effect of type of cereal, heat processing of cereal, and inclusion of fiber in the diet on productive performance and digestive traits of broilers. Poult. Sci. 86: 1705-1715.

Hartini, S. and M. Choct. 2010. The effect of nonstarch polysaccharides derived from different grains on performance and digestive activity in laying hens. J. Indonesian Trop.Anim. Agric. 35(2):95-100.

Hetland, H., M. Choct and B. Svihus. 2004. Role of insoluble non-starch polysaccharides in poultry nutrition. World's Poult. Sci. J. 60: 415-422.

Hetland, H., B. Svihus and A. Krogdahl. 2003. Effects of oat hulls and wood shavings on digestion in broilers and layers fed diets based on whole or ground wheat. Br. Poult. Sci. 44:275-282

Hetland, H. and B. Svihus. 2001. Effect of oat hulls on performance, gut capacity and feed passage time in broiler chickens. Br. Poult. Sci. 42: 354-361

Olugbemi, T.S., S.K. Mutayoba and F.P. Lekule. 2010. Effect of Moringa (Moringa oleifera) inclusion in Cassa based diets fed to broiler chickens. Int. J. Poult. Sci. 9(4):363-367

Sacranie, A., B. Svihus, V. Denstadli, B. Moen, P.A. Iji and M. Choct. 2012. The effect of insoluble fiber and intermittent feeding on gizzard development, gut motility, and performance of broiler chickens. Poult. Sci. 91:693-700

Savory, C. J. 1985. An investigation into the role of the crop in control feeding in Japanese quail and domestic fowls. Physiol. Behav. 35: 917-928

Savory, C. J. 1999. Temporal control of feeding behavior and its association with gastrointestinal function. J. Exp. Zool. 283: 339-347 